University of Nebraska - Lincoln

DigitalCommons@University of Nebraska - Lincoln

$10-2019$

\title{
Presénces polyvalentes: Protean Polynesian Voices In the Works of Rai Chaze and Titaua Peu
}

Julia Frengs

Follow this and additional works at: https://digitalcommons.unl.edu/modlangfrench

Part of the French and Francophone Language and Literature Commons, Polynesian Studies Commons, and the Race, Ethnicity and Post-Colonial Studies Commons

This Article is brought to you for free and open access by the Modern Languages and Literatures, Department of at DigitalCommons@University of Nebraska - Lincoln. It has been accepted for inclusion in French Language and Literature Papers by an authorized administrator of DigitalCommons@University of Nebraska - Lincoln. 


\title{
Présences polyvalentes: Protean Polynesian Voices in the Works of Rai Chaze and Titaua Peu
}

\author{
by Julia L. Frengs
}

IN AN InTERVIEw conducted in May 2013, the same month in which French Polynesia was inscribed on the United Nations list of countries to be decolonized, the archipelago's best-known writer, Chantal Spitz, declared:

\begin{abstract}
L'Océanie est une et multiple. Une parce qu'habitée par un même peuple originel venue d'Asie du Sud-Est, notamment Taiwan, qui s'est installé au fil de voyages océaniques à bord de pirogues à double coque et en suivant les étoiles, sur les îles du Pacifique. Multiple par la variété des adaptations imposées à ce peuple par des environnements géographiques souvent très différents et des colonisations européennes diverses. (19)
\end{abstract}

Spitz evokes the complicated histories that both connect and separate the peoples of Oceania, histories also characterized as "multiple 'translocal' and contested Pacific worlds, sometimes overlapping and often intersecting but always plural" (Armitage and Bashford 9). Simultaneously one and multiple, Oceania, comprised of New Zealand, French Polynesia, the islands of Micronesia and Melanesia, Hawaii, and Easter Island, is a complex, multivalent region, united by a common ancestry yet "separated" by hundreds of indigenous languages (as well as the colonially imposed languages, English, French, and Spanish) and different experiences of colonialism and globalization. The region has recently been producing an equally complex, rich, yet understudied body of literature. In "The Oceanic Imaginary," Fijian scholar Subramani suggests that this literature is a critical site for "the construction of a body of knowledge encompassing the kaleidoscope of Oceanic cultures and tracing diverse and complex forms of knowledge-philosophies, cartographies, languages, genealogies, and repressed knowledges" (151). He envisions a literature that would provide a space for Oceanian voices to question "imagined givens" such as the binary tensions between small and large, indigeneity and introduced, and the notions of space and insularity that he contends are tensions seen in western critical traditions as dialectical, while in Oceania they 
coalesce. Subramani proposes that this aspiration to reimagine Oceania through its own literature-a literature produced by its own people-would, rather than establish any ideological stance, grand narratives, or complete theories, "avoid dreams of completion; it would allow impurities and accommodate important flaws" (151).

I suggest that two contemporary Tahitian women writers, Rai Chaze and Titaua Peu, establish a French Polynesian literary presence in taking up Subramani's call to reimagine Oceania in two novels that illustrate it as simultaneously one and multiple.' Integrating complex forms of indigenous epistemologies such as genealogy-based histories and cartographies with intricate narrative constructions, these authors have created works that are representative of their contemporary social, political, and cultural situations in both form and content. Chaze's Avant la saison des pluies (2011) employs three first-person narrators whose oscillating accounts coalesce around a crucial political moment in recent French Polynesian history, while Titaua Peu's more socially-focused Pina (2016) gives voice to the members of a family on the margins of Tahitian society. Using protean narrative voices, their creative prose provides a space for experimental approaches consistent with Oceanian epistemologies, and resists systems of critical thought that attempt to categorize and continue to marginalize the indigenous peoples of Oceania. These authors' theoretical-literary engagements can also be considered social and political sites of resistance, as both novels expose and critique the colonial and neocolonial systems that have altered the ways of life of $M \bar{a}$ 'ohi communities since the European arrival in the archipelagos in the eighteenth century. ${ }^{2}$ Both authors evoke themes that echo anticolonial theoretical concepts emanating from Anglophone Oceania as well as those from the Francophone literary sphere. While situating themselves within a wider, global literary network, their sociopolitical engagements are locally rooted within a specifically French Polynesian context. ${ }^{3}$

In giving voice to multiple marginalized characters, Chaze and Peu disrupt a complex web of silences. Both authors engage with postcolonial concerns, such as emancipation from imperial powers, social injustices (gender, race, and class), and the lingering colonial systems of representation that render certain portions of the population silent-particularly those of autochthonous heritage. ${ }^{4}$ In the postcolonial literary tradition, freeing oneself, employing first-person narratives, thus breaking colonial-imposed silences, is a method by which the "subaltern" can "challenge conventional ways of telling history" and "restore some control to indigenous peoples" (Muldoon 38). In French Polynesia, however, saying "I" is complicated, as speaking out against the dominating voices of the colonizers means disrupting an internal, traditional silence, sometimes considered protective, of families and small indigenous communities, where the collective voice is valued over that of the individual, and being part of a collective identity is a source of 
pride. ${ }^{5}$ Furthermore, in recounting the realities of a behind-the-scenes Tahiti, the authors unsettle postcard-like images of a vacation paradise. Chaze and Peu break these silences in order to call for the emancipation from a patriarchal colonial system, and to unveil the sociopolitical injustices of a hierarchical society, which does not fit the fantasy of the tropical paradise that persists in the Western imaginary.

In both novels, multiple characters assert distinct narrative voices, contributing to the dynamic, polyvalent nature of the texts, permitting the authors to celebrate individual voices while maintaining Oceanian traditions privileging the collective in a literary community that is comparatively new and searching to establish its own theoretical and conceptual identity. ${ }^{6}$ In the French Polynesian context, this entails establishing a specific, local identity, navigating the political position of still being part of the French state, and situating this position within a larger Oceanian collective context. ${ }^{7}$ As Subramani argues, it is up to Oceanian writers and scholars to discover modes of articulation that encompass Oceanian epistemologies and ontologies. Subramani, Oceanian anthropologist Epeli Hau'ofa, and Filipino-Pohnpeian scholar Vicente Diaz have argued for theories based on archipelagic seafaring traditions, imagining the Oceanian region as one that is interconnected by its histories and networks of migration and settlement, one that is mobile, dynamic, and one that blurs the lines between land and sea. ${ }^{8}$ Diaz suggests that a more "Native" way of talking about the land and about oneself is to talk about sea and identity scapes, or "archipelagic identities," which he defines as "profoundly discursive in constitution, products of narrative acts" that "help us rethink the underlying terms and assumptions about indigenous subjectivity and locality that must nonetheless remain central to broader projects of decolonization and cultural survival inside and outside the Pacific region proper [...] These narrative scapes are as much personal as they are political, and as such, they offer alternative ways of conceptualizing subjectivity in relation to (trans)locality" (10203). I suggest that we view Chaze's Avant la saison des pluies and Peu's Pina as examples of Diaz's notion of archipelagic narrative scapes, as well as responses to Subramani's invitation of different narrative strategies that enable Oceanian writers to reimagine and retextualize Oceanian subjectivity. Thinking in terms of archipelagic narrative scapes enables us to understand the political and personal relationships between the local (Tahiti) and the global (French Polynesia, larger Oceania, and the West) illustrated within these novels.

\section{Narrative Triangulation in Chaze's Avant la saison des pluies}

In Chaze's novel, three characters recount their individual stories that intertwine to narrate the collective political upheaval of the first decade of the twenty-first 
century in French Polynesia. Avant la saison des pluies is constructed as a triptych, divided into three distinct parts, yet the characters share each part unequally. There are frequent flashbacks rendering the chronology quite complicated, as one character recounts events in the present, and the subsequent chapter flashes back 30 years in a different character's life. The triadic construction of the text recalls Diaz's notion of triangulation in the context of archipelagic narrative scapes. In Oceanian seafaring traditions, the distance traveled between islands was calculated by triangulating the islands of departure and destination with that of a third reference island, using the celestial sky as a map for the world below. This triangulation, a way of navigating the Pacific Ocean, was used to negotiate one's position in time and space (Diaz 97-98). Damon Salesa further explains the concept of time/space in Polynesian seafaring societies, noting that there was no direct equivalent to the term "time" in Polynesian languages: "[T] he widely shared Polynesian concept of $w a$, or $v a$, or vaha'a [...] is elaborative: the $v a h a^{\prime} a / v a / w a$ means not just time, but space (and also often relationships). The $v a$ is necessarily relational, implying not a static point of observation but a movement, or possible movement, between" (42-43). ${ }^{9}$ The notion of time/space as a continuum rather than as a splitting of past and present is evident in Chaze's novel, as each character's personal and family histories coalesce in a kaleidoscopic fashion, lending a sense of "deep time," or what Salesa terms "indigenous time," to the text. The narrative present, however, anchors the work in its contemporary political context: the present-tense universe of the novel revolves around the Assemblée de la Polynésie française during the motion of censure of the pro-independence president, the avatar of Oscar Temaru. ${ }^{10}$

While there are three first-person narrators in the novel (in addition to an extradiegetic narrator, who appears occasionally), one voice takes precedence in 25 of the 47 chapters, that of $\mathrm{Te} \mathrm{Ua}$ ("La pluie"). Born during the rainy season in the Tuamotus, she is a métisse with green eyes and light-colored hair. Despite her light coloring, she embodies the legacy of seafaring Oceanians: "Quand on a grandi dans une famille de métis, on n'a aucun problème avec le métissage. Je n'ai pas, comme j'entends souvent le dire, les fesses entre deux chaises. [...] Mes ancêtres, dans leurs lignées, étaient des voyageurs. A leur instar, je vais d'aventure en aventure" (44). Her narrative, like those of the other two first-person narrators in the novel, recounts her upbringing and is punctuated with poetry and terms in her indigenous language, reo mä'ohi. Her chapters also oscillate between recounting the past and narrating the present, where her perspective meets those of the other two narrators, Hiva and Jo.

While the novel opens with Hiva's perspective, he is given the smallest amount of space in the work, narrating only eight chapters, and much of his life and death remains a mystery. Hiva, a $M \bar{a}$ 'ohi born on the island of Tahiti, is quick to point out that he has no trace of royal blood in his lineage (in contrast to $\mathrm{Te} \mathrm{Ua}$, who 
does, as her family frequently reminds her). We also learn that because he is unable to obtain a loan from the bank after his divorce, he lives in his car, a fact he keeps hidden from his daughters, his ex-wife, and his boss. Hiva is the most marginalized and the most tragic of the three narrative "je"s of the work: as an adolescent, his mother sends him to live with his estranged father, who has moved to New Caledonia to work in the nickel mines, as did many French Polynesians in the last half of the twentieth century. An alcoholic, his father abandons him, leaving him to fend for himself alone in an apartment in Nouméa. Hiva's chapters recount only a few memories of his time spent with his mother's side of the family before moving to New Caledonia, his coming-of-age in New Caledonia, and the present, where he meets $\mathrm{Te} \mathrm{Ua}$ at the first meeting to discuss the motion of censure taking place at the Assemblée de la Polynésie française. The two characters fall in love, but this relationship is brief. After a day drinking with colleagues, Hiva expresses his frustration with the political situation of his country and decides to spend the night next to the ocean. Indigenous voices, bodies, and seascapes meld as we learn of the character's watery demise. Hiva imagines hearing his mother singing a Māori lament, calling to him from the lagoon, and follows her voice." As he follows her, he envisions "les cheveux gris flotter, puis s'enrouler aux coraux et se mêler aux poissons qui passaient par là..." (280). In the following chapter, Te Ua "sentit un long cri s'échapper du fond de la mer" (281) and reads of Hiva's death in the next morning's newspaper.

We meet Jo in the eleventh chapter of the first part of the novel, joining him in one of the frequent flashbacks on an adventure in the New Caledonian bush in the 1980 s. This decade, known as Les événements, was a turbulent period during which the autochthonous Kanak population organized revolts, protests, and strikes, demanding independence from France. At fifteen years old, Jo had moved to the island from Tahiti to live with his grandmother while his parents were divorcing. Feeling no affinity with the French population, he found a sense of brotherhood with the Kanak, "un peuple colonisé comme chez lui" (79). The narrator observes that in Kanaky/Nouvelle-Calédonie, Jo learned that he was not French:

Il fallait qu'il soit sorti de son île pour prendre conscience de son identité. Son exil imprévu l'avait amené à se rendre compte de sa différence. Il n'était pas français, mais un taata Tahiti, même s'il avait hérité de ses ancêtres popaâ une peau claire. Il parlait comme un Tahitien, un accent doux et trainant, parfois chantant. Il marchait et dansait comme un Tahitien. Il parlait le reo tahiti mieux que le français... $(79-80)^{12}$

Like Hiva, Jo must leave his island to discover his identity as Tahitian. Through these characters' self-discoveries in another colonized Oceanian island, Chaze 
recalls the interconnections between the islands of the Pacific Ocean, extending beyond French Polynesia to Melanesia. Despite the vast differences between the types of colonization the two indigenous groups experienced, recognizing the shared experience of having been victims of French imperialism reinforces a sense of inter-Oceanic solidarity, the connections between the islands serving to chart an archipelagic narrative scape.

Following his séjour in Kanaky, Jo returns to Tahiti to live with his mother and stepfather, obtains his diplomas, begins working for a boat company run by a businessman known for his demanding nature, and unwittingly becomes entangled in risky clandestine operations, spying on this man's enemies, clients, and journalists. Inevitably, as the lackey for the dubious characters running the company, when the businessman disappears and the company's machinations are discovered, Jo takes the fall. Accused of terrorism, Jo is unable to defend himself, due to his inability to master the French language, and receives a stricter sentence than should be expected for his level of involvement in the scandal. He is imprisoned in the Nuutania penitentiary, frequently in the news due to its overcrowded, deplorable conditions.

The three narratives mainly intertwine in Te Ua's accounts, in which I suggest a narrative triangulation occurs. In part two of the novel (while Hiva is still alive in the narrative present), we see the debate over identity, local Mä'ohi independence, and the $M \bar{a}$ 'ohi place in the Oceanian framework fuse. Te Ua and Hiva become fascinated with Jo's story: "C'était pour nous, des façons de faire occidentales, que nous n'avions vues jusque-là qu'à la télé ou au cinéma" (182). The conversation leads to lamentations about the political state of their country, and to a reimagining, and a renaming, of their region:

Hiva aimait rêver d'un peuple réuni de par le Pacifique: le peuple polynésien de Moana Nui rassemblant les habitants du triangle polynésien. Nous nous sommes mis à rêver et parler de ce jour plus ou moins lointain, où nous pourrons voyager avec un passeport qui dit, selon Hiva, que nous sommes citoyens de Tahiti Nui appelée aujourd'hui la Polynésie. Hiva poussait plus loin l'utopie: - Un jour, nous serons citoyens de Moana Nui délimité par Hawaï, Aotearoa et Rapa Nui, comme nous l'étions au commencement. $(183)^{13}$

This renaming, though, is not a selection of a new name. It is a return to the panPolynesian designation ancient seafaring voyagers gave to what we know as the Polynesian triangle thousands of years ago. Through Hiva and Te Ua's vision of a unified Polynesian triangle, through the characters' travels throughout Oceanian islands and references to other Oceanian indigenous groups' independence struggles, but with a focus throughout the novel on a particular moment in the French Polynesian independence debate, Chaze proposes a reimagined archipelagic identity 
that integrates shared Oceanian epistemologies and ontologies with the locally specific (and multiple) histories and stories of Tahiti and its people.

\section{Plurality and Genealogy in Peu's "roman corail"}

While Chaze's novel employs three main characters to chart a narrative triangulation signaling an archipelagic narrative identity, Titaua Peu's Pina is recounted in even more polyphony, giving voice to almost all the members of a family of nine children. Additionally, the author includes her own interventions, in which she speaks directly to the reader. Peu's choice to include such a plethora of voices is a literary experiment in creating a new Oceanian theoretical framework, or an attempt to articulate a sense of archipelagic identity: "[J]e voulais travailler sur le roman corail, avec plusieurs voix, plusieurs personnages, qui vont tous se retrouver autour d'une figure symbolique, et voilà Pina. Pina, c'est pas seulement la petite fille, Pina, c'est le pays douloureux..." ("Interview"11:45). The use of the coral reef as a model for the construction of this novel is revelatory. As Elizabeth DeLoughrey notes, while coral reefs occupy less than one percent of our oceans, they are home to nearly one-third of known marine species and can grow so large that some can be seen from space. Made up of a bacterial community of coral mucus, coral live in symbiotic relationships with fish, turtles, algae, sponges, and more, making them multispecies creatures, reflecting the polyvalence of Peu's novel: " $[\mathrm{C}]$ oral signifies deep time. Its limestone structure means it layers growth like bone [...] it grows extremely slowly and its life span is undetermined" (DeLoughrey 40). While DeLoughrey's work focuses on Caribbean writers who have imaginatively figured humans in the limestone structures of coral reefs to reflect the traumatic, un-localizeable relationships between slavery and the sea, coral in the Pacific or Oceanian context can function in a similarly metaphorical manner, as an "oceanic archive [of] the remnants of imperial debris and ancestral origins" (35). Conceptualizing both novels as metaphorical coral reefs is especially illustrative, considering the importance of genealogy to Oceanian epistemologies and the notion of $v a$ (time/space), or deep "indigenous time" discussed above. Like the coral reef, genealogy is anchored in the past, yet escapes it, as one cannot predict its refracted, kaleidoscopic trajectory.

The archipelagic scape of a "roman corail," a multispecies creature indicative of deep time, is evident in several aspects of Peu's Pina. It is reflected structurally, in the use of multiple narrative voices: the author employs the first-person "je" when recounting the story through Pina's perspective and rarely in the accounts of other characters. The chapters dedicated to the other main characters to whose perspectives we are privy (Pina's mother, Ma, her eldest sister, Hannah, her abusive father, Auguste, and her brothers Auguste Junior and Pauro) are each recounted in a third-person limited voice, giving the impression that it is indeed Pina's voice 
that is privileged. The idea of the "roman corail" is also reflected in the use of italicized asides that introduce the novel and intermittently interrupt the principal diegesis. These asides begin with: "Un petit corps balance. Plutôt, il tournoie, à demi. Calmement, c'est excessif ce calme. Il laisse entendre que le dernier sursaut a eu lieu, c'est plus la peine" (7). To each subsequent aside dispersed throughout the novel, the author adds one or two sentences, contributing to the element of suspense. This technique also reinforces the idea that everything that happens in this story turns around or builds upon the figure of Pina, who represents, as Peu says, the suffering country. The reader experiences an almost palpable sensation of the narratives building on one another as the skeleton of coral hardens, gradually forming large reefs.

Pina takes place in the district of Tenaho, a housing project close to the capital city of Papeete. After driving drunk and killing a woman in a car accident, the father of the family, Auguste, is found comatose in a hospital. This father is a monster: he beats his wife, he ignores his children, he drinks and stays out late at night. Twenty-something Auguste Junior wanders the streets, committing petty crimes and smoking cannabis. A drug-addicted, teenaged Rosa prostitutes herself, while Hannah, the eldest daughter, who has not spoken to her family in years, struggles to earn a living in Paris (in the middle of the novel, she returns to Tahiti with her boyfriend, a French writer). Pauro discovers his homosexuality at the age of 16 with a French architect who lives in the fenua (country), and nine-year-old Pina must clean the house and take care of the baby, Moïra, because her mother, $\mathrm{Ma}$, either cannot move due to her injuries, or she is absent. After visiting Auguste at the hospital, Ma meets the husband of the woman Auguste has killed. Both filled with grief and overcome by emotion, they make love and eventually begin a relationship. When Auguste miraculously awakens from his coma, he becomes devoutly religious and attempts to repair the damage he has done to his family, but when he learns of his wife's affair, jealousy overcomes him and he resumes beating her. After a vengeful killing spree, the brutal Auguste, delirious, cannot resist his daughter Pina. The family returns home to find Pina hanging, an attempt at suicide. Ma subsequently kills Auguste, and a relative insists on taking the responsibility for this crime, as he expects to die of cancer within two months. ${ }^{14}$

In an audacious move, Peu chooses to expose the imperfections in the lives of a family, as the family space should customarily remain the most intimate, private space of a community, certainly within Oceanian indigenous tradition. The author insists, however, that "toutes les histoires commencent par des histoires de famille" (Pina 13), recalling the Oceanian tradition of recounting genealogies, and indicating that the family, at the epicenter of the novel, is a microcosm for a Polynesian society losing its identity and its history. Yet, Peu is not shy to critique her society's patriarchal traditions. As in her first novel, Mutismes (2003), Peu links domestic violence with social violence and associates both European and Oceanian heritage 
with this violence. Within the context of sociological statistics, the focus on domestic violence in the text is not surprising. A 2007 study on violence toward women in French Polynesia conducted by Patrick Cerf indicates that 1 in 10 women in French Polynesia is a victim of conjugal violence. Cerf attributes this statistic to the valorization of virility and to the violence inherited from an autochthonous society of warrior tradition: "Dans la société tahitienne contemporaine, la force physique et la violence font toujours partie des prérogatives masculines les plus gratifiantes et un homme qui sait se battre jouit d'un respect et d'un prestige réel" (290). Concerning the psychology behind this conjugal violence, Cerf refers to Polynesian myths that associated women with danger. For example, ancient Mãoris described the sexual act as a battle between female and male sexual organs (291). In one pan-Polynesian legend, the demigod Maui dies while trying to penetrate Hine-nui-te-po, the goddess of the night: the vagina thus represents a path toward both life and death. Cerf suggests that these ancient myths and legends have left their traces in the collective consciousness of modern Polynesian societies. Cerf remarks, however, that anthropological studies show that violence toward women was not as frequent in traditional Oceanian societies as it became after the arrival of Europeans, as nineteenth-century missionaries brought additional beliefs that women were inferior. Taboos about tribal wars and open violence contributed to repression and now manifest themselves in the-secret-form of conjugal violence. This violence appears in Peu's novel as an inherited trait from both major ethnicities (Ma'ohi and European) that constitute French Polynesia's demographics.

The novel functions as a commentary on domestic violence as a symptom of colonial domination and contemporary social injustices. Like Chaze does with her discourse on independence, Peu interweaves interjections on specifically contemporary French Polynesian social issues with Oceanian ways of being and knowing the world, delineating a tragic archipelagic narrative scape. In a chapter entitled "L'endroit de toutes les possibilités," which recounts the memories of the abusive father Auguste's upbringing, the author explores the idea of inherited domestic violence and warrior mentalities. In this chapter, we learn about the violent colonial period in French Polynesia through the perspective of Auguste's ancestors on the island of Raiatea, the mythical birthplace of Polynesian people and culture. The first Maxoris are said to have departed from this central island in immense voyaging canoes, or $v a$ 'a, to colonize the rest of Polynesia. This island is thus heavily symbolic, a part of the genealogical and mythical heritage of all Polynesian peoples. Moreover, Raiatea is known as the island of resistance: while Tahiti officially became French in 1880, Raiatea resisted until 1888, when France annexed the island and provoked a violent insurrection. The narrator recounts a fictional version of the resistance, with Auguste's great grandfather, Matahi, warrior-hero, at the center. The traces of this warrior and of a failed resistance remain not only in the collective memory of the family, but are archived in the landscape as well: 
"Aujourd'hui, de cette guerre, peu de stigmates. Les silençes se sont installés ou alors les mots sont voilés. Sauf dans la famille d'Auguste. Aujourd'hui, il y a un chant qui parle de Matahi [...] Juste un chant. Intime et douloureux. Rien qu'un chant pour dire la mélancolie de la terre écorchée" (103). This chapter reveals that Auguste's family, plagued by the colonial violence inflicted on the land, is cursed with an inherited violence. At the end of the chapter, we learn that Auguste's mother kills his equally violent father, and it is Auguste who discovers his body. Much later, when Auguste recovers from his coma and becomes a born-again Christian, he still cannot escape this inherited violence. Horrified by the corruption and scandals he observes working as a bodyguard at a nightclub, Auguste begins a killing spree, targeting rich drug lords who profit at the expense of the poor, legitimizing this violence as part of his mission: "C'était sa mission et celle de sa mère [...] Il était Matahi, celui qui ne plie pas sous les balles. Il était l'ancêtre héroïque, fier, altier, démoniaque" (323-24). The author seems to imply that violence is instilled in the family lineage, an inevitable destiny. Yet, while violence appears to be predetermined, so too does the spirit of resistance: by the end of the novel, the older children, now united with a half-brother, policeman Maui, join the Polynesian independence movement. Maui reflects on this seemingly paradoxical inheritance, a warrior-blood that can either lead to violence or help to resist contemporary remnants of colonial oppression: "Frères d'armes puis de sang. Descendants de révoltés. Refusant le nouvel ordre et... fils d'assassin" (331). The character's reflection on this paradox in the context of the independence movement mirrors the space-time conundrum Peu encounters in inscribing genealogy-based Oceanian history into a contemporary, unequivocally political text.

Rather than offer a definitive solution or complete theories against which Subramani warns, Peu, like Chaze, represents "indigenous" or deep time symbiotically, through the mixing of multiple stories. Allowing time and space to refract through different pre- and post-colonial experiences, like the ocean or the coral reef, these authors create archipelagic narrative scapes that encompass an Oceanian way of knowing and of existing in the world. As Subramani suggests, Oceanian literatures should "allow for impurities and accommodate important flaws" (151). Avant la saison des pluies and Pina expose the violence, the marginalization, and the political corruption inherited from colonial history, from contemporary neocolonial institutions, and from autochthonous traditions. As Te Ua laments: "Aujourd'hui, notre peuple est en guerre, l'un contre l'autre. Comme si nous avions dans notre sang la mémoire du passé [...] Les humiliations, mépris, haines, colères et meurtres du passé sont toujours présents dans nos veines. Nous essayons de perpétuer les enseignements de nos tupuna [ancêtres], mais les sangs mélangés en nous se disputent" (350). Through these somber depictions of a society embroiled in battles for independence, social justice, and internal local conceptions of identity, the two authors establish for themselves a specifically French Polynesian 
Oceanian literary presence. Chaze and Peu create kaleidoscopes of personal stories, using indigenous modes of articulation that intertwine to disseminate a larger history and repressed knowledges. Whether narrative triangulations recalling Moana $\mathrm{Nui}$, the Polynesian triangle, or the "roman corail," where multiple voices build around a central figure, these writers employ non-linear chronologies, collective histories, and personal stories to evince the notion of deep or "indigenous" time. As they refuse to draw a distinction between past and present, these novels express the way the Má'ohi people know themselves and understand their world. Combining discourses of emancipation, cries for social justice, intertwined genealogies, and critiques of both their own and the colonizing societies through collages of protean voices, Chaze's and Peu's innovative narrative archipelagic scapes enable them to reimagine Oceanian literature of French expression as both one and multiple.

\section{UNIVERSITY OF NEBRASKa, LINCOLN}

\section{Notes}

'Chaze and Peu were born in Tahiti (in 1950 and 1969, respectively), and while raised in different social milieus, both identify as Tahitian and recognize their $M \bar{a}^{\prime} o h i$ (indigenous from French Polynesia) ancestry as integral to the understanding of their identities.

${ }^{2}$ The term Ma'ohi designates indigenous peoples from French Polynesia, which are divided into five groups: the Society Islands, where Tahiti is located, the Tuamotus, the Gambier Islands, the Marquesas Islands, and the Austral Islands. Reo ma'ohi is the umbrella term that encompasses the seven indigenous languages spoken in French Polynesia.

${ }^{3}$ It is also notable that these contemporary writers are women, and while they may not identify themselves as "feminist" writers or as participating in écriture féminine, both place sociopolitically-engaged female characters at the forefront of their works. In the last two decades, French Polynesia has seen an abundance of literature produced by women of $M a \hat{a}$ ohi descent, including Chantal Spitz, Flora Devatine, Ari'irau RichardVivi, and the two authors examined here.

"Although it enjoys more autonomy than the départements d'outre-mer, French Polynesia remains a collectivité d'outre-mer, and citizens carry French passports. It is currently a "pays d'outre-mer au sein de la République."

sFor more on multiple narrative "je"s and speaking out in a Tahitian context, see Frengs.

${ }^{6}$ Peu and Chaze are not the first French Polynesian authors to employ multiple narrative voices. In Elles, terre d'enfance, Spitz gives voice to two Tahitian women, literally separating their narratives in typographically distinguished colored inks. In 
Moetai Brotherson's Le roi absent, two very different first-person narrators force the reader to question narrative authority and "authenticity."

'This is especially important given the relatively marginalized position of Francophone Oceanian literature in comparison to Anglophone Oceanian literature. In the vast expanse of Oceania, French is the (or one of the) official language(s) of only four geopolitical entities: French Polynesia, New Caledonia, Vanuatu, and Wallis and Futuna. It is imperative, therefore, that these writers engage with the literature flourishing around them, while establishing a local presence (rendered even more complicated by the tenuous relationship between local Mä'ohi languages, French, and francotahitien).

${ }^{8}$ Likewise, the $v a$ ' $a$, or the Oceanian voyaging canoe, has frequently been used as a metaphorical lens through which to envision the mobile nature of Oceanian literature. For more on mobility in Francophone Oceanian literatures, see Francosphères 6.2 (2017): "Interconnections and Mobilities: The Pacific Francosphère."

'In the Dictionnaire de l'Académie tahitienne<farevanaa.pf/dictionnaire.php>, $v$ is translated as "espace de temps."

${ }^{10} \mathrm{Temaru}$ has been a pro-independence political leader in French Polynesia since the 1970s, when he founded Tavini Huiraatira (the People's Servant Party). Between 2004 and 2013, he served as president of French Polynesia five times.

"Māori refers to the autochthonous peoples of New Zealand.

${ }^{12}$ Taata Tahiti means "a Tahitian person." The term can refer to a person of $M \bar{a}$ 'ohi descent or one of mixed heritage (generally referred to as "demi" in Tahiti). Popaâ means "white foreigner."

${ }^{13}$ Aotearoa is the Mă'ori name for New Zealand. Rapa Nui is Easter Island, off the coast of Chile. Hawaii, Aotearoa, and Rapa Nui mark the three points of the Polynesian Triangle. In reo Mä’ohi, Moana Nui means "Big Ocean."

${ }^{14}$ In both novels, several relatives of the principal characters succumb to cancers, which the authors both attribute to the nuclear testing performed in French Polynesia from the 1960s until the 1990s. In Avant la saison des pluies, Chaze points out: "[N]ous avons cinq cents nouveaux cas de cancer par an [...] Une population se meurt et la France persiste à dire avoir eu la seule bombe inoffensive au monde!" (202). As nuclear testing was a catalyst of the Polynesian independence movement, this is another way in which the authors intertwine contemporary politics with personal histories.

\section{Works Cited}

Armitage, David, and Alison Bashford, eds. Pacific Histories: Ocean, Land, People. Palgrave Macmillan, 2014.

Brotherson, Moetai. Le roi absent. Au vent des îles, 2007.

Cerf, Patrick. La domination des femmes à Tahiti: des violences envers les femmes au discours du matriarcat. Au vent des îles, 2007. 
Chaze, Rai. Avant la saison des pluies. Présumés, 2010.

DeLoughrey, Elizabeth. "Submarine Futures of the Anthropocene." Comparative Literature 69.1 (2017): 32-44.

Diaz, Vicente. "No Island Is an Island." Native Studies Keywords. Ed. Stephanie Nohelani Teves, et al. UP of Arizona, 2015. 90-108.

Frengs, Julia L. "'Comment te dire la dualité entre l'une et l'autre moi-même': The Double 'Je' of Chantal T. Spitz's Elles, terre d'enfance: roman d deux encres." Protean Selves. Ed. Adrienne Angelo and Erika Fülöp. Cambridge Scholars, 2014. 11-27.

Hau'ofa, Epeli. We Are the Ocean. UP of Hawaii, 2008.

Muldoon, Paul. "Between Speech and Silence: The Postcolonial Critic and the Idea of Emancipation." Critical Horizons 2.1 (2001): 33-59.

Peu, Titaua. Pina. Au vent des îles, 2016. . "Titaua Peu, Pina, interview au salon du livre de Tahiti 2016". 14 novembre 2016. <youtube.com/watch?v=ldIn7-UXCCk>.

Salesa, Damon. "The Pacific in Indigenous Time." Armitage and Bashford 31-52.

Spitz, Chantal. Elles, terre d'enfance: roman à deux encres. Au vent des îles, 2011. . Entretien: "Colère salutaire". Pages de Bretagne 33 (juin 2013): 19-21. <livrelecturebretagne.fr/wp-content/uploads/2013/07/PagesdeBretagnenumero33-web.pdf $>$.

Subramani. "The Oceanic Imaginary." Contemporary Pacific 13.1 (2001): 149-62. 